\title{
Japanese Regulation of Truck Transport
}

\author{
David Flath
}

Working Paper No. 119

A version of this paper was presented at the conference Micro-economic Reform and Deregulation in Japan held at Columbia University on March 22-23, 1996.

Working Paper Series Center on Japanese Economy and Business Columbia Business School June 1996 


\title{
JAPANESE REGULATION OF TRUCK TRANSPORT
}

\author{
David Flath*
}

\begin{abstract}
Since 1951 the ministry of transport has been vested with sweeping authority to restrict entry and set prices in commercial trucking. Perhaps it could have used this authority to cartelize the industry. The weight of evidence holds that it did not do so. There is little to suggest that the standard price schedules which the MOT continues to publicize and periodically revise are anything more than suggestions, widely disregarded by commercial trucking firms. There are no economies or diseconomies of scale and firms have expanded until industry profits are exhausted. The changes in truck transport regulation introduced in 1991 were mainly directed at freeing a new activity, parcel delivery service, from regulatory constraints, and spreading some of the benefits to others in the industry. The principle remaining effect of truck transport regulation in Japan has been to impose a cost on private trucking operations (companies that use their own trucks to deliver their own merchandise) by legally barring them from also undertaking commercial business. If this restraint were to be lifted, the supply of trucking services would be enlarged and in the transition to a new (zero profit) equilibrium commercial truckers would suffer losses and some would exit.
\end{abstract}

*Department of Economics, NCSU, Raleigh, NC 27695-7506, USA. tel.(919)515-2472; fax.(919) 515-5613.

I gratefully acknowledge the generous support of Osaka Gas Company. Also, for their assistance in obtaining data on the trucking industry of Japan I thank the following: Y. Shirakashi (Osaka torakku kyoukai), H. Mita (uñyu keizai ken̄kyū señtā), and Y. Yamashita (kin̄ki uñyu kyoku, uñyushou). 
1. Introduction.

The Japanese trucking industry nicely epitomizes a curious aspect of regulation in Japan: Although many have remarked on the ubiquity, intrusiveness and inefficiency of government regulation in Japan, one searches nearly in vain for economic analyses of the actual effects of regulation in Japan. From 1951 the Ministry of Transport was vested with sweeping authority to restrict entry and regulate prices in the trucking industry. Yet in spite of the annual flood of government reports on the industry's production, operating characteristics, and so on, there exist no estimates of how the performance of the industry might have been different in the absence of regulation. Contrast with the US is stark. A voluminous academic literature established that Interstate Commerce Commission restrictions on entry and pricing had effectively cartelized the trucking industry (from 1935 to 1980), and, as it turns out, accurately predicted the effects of deregulation on industry capital values and labor earnings. Since 1991 the trucking industry of Japan has been subject to a revised set of regulations which nominally represent relaxation of government restraints on entry and pricing. Yet just as the effects of the original regulatory regime were unknown, so too the effects of change in regime remain unplumbed. The goal of this study is to analyze the effects of regulation (and 1991 changes in regulation) on prices and rents in Japan's trucking industry. What we discover is that truck transport regulation in Japan has not been nearly as costly, distorting, and intrusive as it was in the US.

Regulation has not produced a sweeping cartelization of truck transport in Japan, as it did in the US. The changes in truck transport regulation introduced in 1991 were mainly directed at freeing a new activity, parcel delivery service, from regulatory constraints, and spreading some of the benefits to others in the industry. The principle remaining effect of truck transport regulation in Japan has been to impose a cost on private trucking operations (companies that use their own trucks to deliver their own merchandise) by legally barring them from also undertaking commercial business. Commercial truckers have expanded their own operations until industry profits are exhausted. The end result is a system 
in which private truckers undertake less commercial business than is economically efficient and commercial truckers undertake more. Further relaxation of truck transport regulation in Japan would reduce the number of empty trucks on the roadways there but would not lead to a significant reduction in fares.

One of the keys to analysis of Japan's truck transport industry is its absence of economies of scale, which below we document with estimates of cost functions. The picture that emerges is an industry in which rents are exhausted, subject to the regulatory constraints. When parcel delivery service rapidly developed in the 1980's and the regulatory constraints began to impose large and visible deadweight costs, the competition among political pressure groups forced a change, just as Becker's (1983) theory anticipated. And as Peltzman's (1976) theory anticipated, in the movement from one political equilibrium to another, the benefits got spread among pressure groups, not concentrated solely on one.

\section{Trucking regulations of Japan.}

Regulation of truck transport in Japan originated during the Occupation era. The Railway Express Enterprise Law of 1949 established price and entry regulation of the trucking services connected with rail shipments. The Road Transportation Law of 1951 divided remaining commercial trucking firms into two categories, route truckers and area truckers. Route truckers were licensed to serve particular routes on regular timetables, and were permitted to serve customers on a less than truckload basis. That is multiple shipments could be combined on the same truck. The area truckers were licensed to serve one customer at a time on consignment within a designated region. That is they were permitted to offer shipments on a full truckload basis only. Besides these, specialized vehicles such as refrigerator trucks, tank trucks, and hearses are in a distinct category but their numbers are small in comparison to the others. Amendments to the laws in 1971 abolished the distinction between area truckers and those offering services connected with rail shipments, leaving intact the distinction between area truckers and route truckers.

The number of route trucking firms (less-than-truckload firms) has steadily 
declined from 533 in 1960 to 325 in 1989 (See table 1.). Area trucking firms (general trucking firms) tend to be smaller than route truckers and their numbers have steadily risen over the years from 28,523 in 1975 to 35,888 in 1989 (Again, see table 1). Area trucks account for more than 80 percent of the operating income of commercial trucks. Parcel delivery service is conducted by route trucking firms. The rapid growth of parcel delivery service beginning about 1985 led to enactment in December 1989 of the Motor Vehicle Law, a complete revamping of truck transport regulation which took effect in 1991. The new statute abolished licensing (meñkyo) of commercial truck firms and instated a permit (kyoka) system. Under the new system, the firms formerly holding route trucking licenses were no longer required to adhere to fixed time schedules nor make pickups and deliveries at pre-set locations. Parcels could now be picked up and delivered at the customers' own premises rather than only at dropsites stipulated in MOT licenses--the troublesome feature of the earlier regime which elicited effective political opposition to it. The new permits specify geographic regions of operation but the companies specializing in parcel delivery hold in effect nation-wide coverage of permits. Additionally, the former holders of area trucking licenses now have been issued permits that allow them to combine shipments of differing customers (less-than-truckload shipments). In principle the permits now held by route trucking firms and area trucking firms no longer differ. However, there does still exist a de-facto distinction between the two types of firms. Long distance shipping including parcel delivery is mainly confined to the firms with networks of terminals. These, the former holders of route trucking licenses, are still referred to in the industry and in government surveys as the "less-than-truckload" companies (tokubetsu tsumiawase). The others, including mostly former holders of area licenses, are referred to as "general" trucking firms (ippañ).

A significant portion of truck transport in Japan has always been for private use and therefore not regulated. Many large companies in Japan deliver their own merchandise rather than hiring the services of commercial truckers. Private trucks account for nearly two thirds of goods shipped by truck in Japan, 
by weight, but account for only about one fourth of shipments measured by tonkilometers (See table 3). Private trucks tend to ship goods over shorter distances than do commercial trucks. The percentage of tonnage shipped by private truckers rather than commercial ones shows a slight secular trend downward over the last fifteen years. Though not regulated, private truckers are required to notify the MOT of their operations and are effectively prohibited from obtaining authorization to also transact commercial trucking business (though they have devised ways of getting around this prohibition, about which more, shortly).

At the time the Motor Vehicle Law was enacted it was widely hailed as a relaxation of regulation (kisei kañwa). Partly this is because, as already indicated, route truckers were no longer confined to pre-set time schedules and drop sites and area truckers were no longer restricted to full truckload shipments. Additionally, regulation of fares was nominally relaxed. The 1989 Motor Vehicle Law changed the method of price regulation from one in which the MOT stipulated legal minimum and maximum fares to one in which firms are only obliged to notify the MOT of fare changes, which it may disallow. Under the earlier regime of the 1951 Road Transport Law the MOT published standard rate schedules which beginning in the mid-1970's it revised every couple of years. The schedules specified ranges within which prices could legally be set, generally allowing deviations of about 108 above or below set amounts that depended on distance and weight in the case of route trucks, and depended on truck size and either time in transit or weight of load in the case of area trucks (whichever was the least binding constraint). A 1972 survey of 157 route trucking transactions and 410 area trucking transactions found that actual prices were below the legal minimum in many instances.' Fronthauls were generally priced within ten percent of standard rates but backhauls were discounted by about thirty percent below standard rates. Many commentators have suggested that price regulation under the Road Transport Law exhibited a degree of softness, but

\footnotetext{
'T. Murao, torakku uñyu shijou kouzou no ichisokumeñ to uñchin̄ no jittai (one-sided structure of the truck transport market and the actual condition of rates), nittsuu sougou keñkyuujou...discussed in Murao (1982), p. 97 and p.320.
} 
without presenting evidence. ${ }^{2}$ The 1989 Law in effect acknowledges softness of price regulation as the status quo.

The substitution of a "permit" (kyoka) system for one of licenses (meñkyo) means that all applicants meeting a set of published criteria will now be allowed entry, whereas before, the MOT was authorized to bar entry or bar expansion of service by incumbents, more or less arbitrarily. There does exist some fudge wording in the 1989 Law authorizing the MOT to bar further entry if it deems that "competition is excessive", but so far it has not invoked this clause. The published criteria for obtaining a permit include minimum truck fleet sizes, ranging from 3 trucks to 15 trucks (These vary among the 10 MOT regional offices), with the added stipulation that the trucks are owned rather than leased. Also, there are stipulations regarding adequate office facilities, parking, employment of qualified personnel and so on. In the case of area trucking all this might actually represent a hardening of entry regulation rather than softening. In any event, expansion by incumbents is likely to have exhausted whatever rents are conferred by restriction of new entry. As we document below, the industry does not exhibit economies of scale so expansion by incumbents is no more costly than new entry. And expansion by incumbents under both the old regime and the current one has often not required the issuance of new licenses or permits.

The factor which precipitated enactment of the 1989 Law was growth of the parcel delivery service. The transport ministry does not report income from parcel delivery separately from that of other commercial truckers but (as noted by Saitou, 1991, p. 45) an article in nikkei shinbun indicated that in 1985 the revenues from private parcel delivery amounted to 323,000 million yen, approximately 27.98 of the operating income of route trucking firms as a group, and 4.48 of the operating income of all commercial trucks. ${ }^{3}$ From 1985 to 1990

${ }^{2}$ Refer for example to the following: Goto and Sugiyama (1983); Sugiyama (1989); Takahashi (1990); and Takeuchi and Terada (1995).

${ }^{3}$ takuhaibin̄ uñchin̄ no subete (all about parcel delivery service fares), nikkei shiñbuñ, November $20,1985$. 
the number of parcels delivered by route truckers doubled (See table 4 ). Assuming, rather conservatively, that revenue per parcel was unchanged from the 655 yen/parcel received in 1985, this would mean that in 1990 parcel delivery accounted for nearly $40 z$ of the operating income of less-than-truckload truckers and nearly 7 percent of the operating income of all truckers. In the last ten years, parcel delivery service has been by far the most rapidly growing segment of commercial trucking.

The growth of parcel delivery service in Japan mirrored the expansion of Federal Express and United Parcel Service in the US. In Japan, Yamato uñyu (takkyuu-biñ) was the innovator and it retains its dominance of the industry. Yamato and its three subsidiaries accounted for $44.3 \%$ of parcel deliveries in 1993 followed by nippoñ tsuun (perikan̄-biñ) and its 22 related companies with 26.28. The Yamato logo, a black cat carrying its kitten in its mouth, has become a very familiar sight on trucks all over Japan. Beginning around 1980 Yamato began to introduce parcel delivery service in a major way, based on a constellation of innovations: ${ }^{4}$ (1) A nationwide system of truck terminals, extending a logistical net throughout the country and enabling next-day delivery over an extremely wide region. (2) Wireless communication directly with truck drivers while enroute ("multichannel access"). (3) Computerization of instructions and tracking of parcels. (4) Linkage of computer networks with one another ("value-added networks"). Within a few years, these innovations were imitated by nittsuu and others. The improvement in logistics and communications which these innovations supported, had made it cost effective to greatly increase the number of dropsites on truck routes, and to offer customers assurances of special handling or express delivery.

By 1985, parcel delivery service was becoming a major rival to postal parcel delivery service and had virtually displaced parcel shipment by rail. But the regulation of route trucking was ill suited to the new activity in several ways. First, the route licenses bound the trucks to specified stops, often at retail detail.

The excellent little book by Saitou (1991), describes these innovations in 
stores such as rice shops or liquor stores, while the new technology had made it economical to offer door-to-door pick-up and delivery. Second, even Yamato, the holder of the most kilometers of licensed routes was still unable to offer nationwide parcel delivery without further acquisition of licenses or subcontracting out to firms that already held licenses. And finally, the standard pricing schedules of the MOT were poorly adapted to parcels as small as those the route truckers were now transporting--the sensible way of pricing parcel delivery was by the item, not by weight.

From 1983 to 1988 Yamato greatly expanded its network by acquiring other route companies to obtain their licenses, and by obtaining new licenses, but it was frustrated in its attempts to achieve truly nationwide coverage. In particular, in Yamagata prefecture, incumbent holders of route licenses successfully opposed Yamato's application to obtain licenses there (Saitou, 1991; pp. 141-147). Only the enactment of the 1989 Act resolved matters in Yamato's favor, and at the same instant it largely removed the other onerous regulatory constraints on parcel delivery service also--at least this was true for Yamato.

A couple of other occurrences, germane to the expansion of parcel delivery service in Japan also merit comment. About 1988 the American company Federal Express sought and obtained permission to deliver parcels to Japan and deliver them within Japan. The granting of these rights to FedEx had been requested by the US government with clear linkage to the ongoing trade negotiations. ${ }^{5}$ Foreign pressure to relax regulatory constraints on parcel delivery were thus added to domestic pressure.

And finally, in February 1992 the president and other top officials of Tokyo Sagawa kyuubin were arrested and charged with extending fraudulent loans of more than 30-billion yen (more than 200-million SUS) to affiliates of the Inagawa crime syndicate. The money was being funnelled to 100 politicians in the Liberal Democratic Party, including $s$. Kanemaru, the head of a leading faction. It was subsequently reported that among the intended objects of the bribery was the

5On the chronology of Federal Expresses attempts to gain these concessions refer to Ligon (1993). 
successful disposition of Sagawa's application to greatly expand its licensed area. Sagawa's parcel delivery service remains quite minor relative to the industry leaders. This leads directly to a fundamental question regarding the effects of truck transport regulation: Has it produced a stream of economic rents? The answer is a resounding: maybe, but not a very large stream.

3. Evidence of economic rent.

One of the most convincing demonstrations that us trucking regulation generated cartel rents was that permits themselves were bought and sold at sizeable prices, about a third of the amount of annual revenue generated by the business which the permit allowed (Moore (1978); Frew (1981)). The market value of permits represents a pure rent, (one which accrues not necessarily to the current permit holders but rather to the happy few who were first issued the valuable permits without having had to pay for them). The prices at which permits were transferred were reported to the US regulatory authorities, and therefore became a matter of public record subject to the scrutiny of economists and others.

There exists evidence that trucking permits in Japan too have been traded, and hold a market value which is the capitalization of rent. But unlike the US case, the prices at which permits have been traded are not at all a matter of public record. Murao (1982; table 7-18, p. 323) lists the number of instances annually from 1964 through 1980 in which area trucking licenses and route trucking licenses were transferred from one party to another (Murao obtained the unpublished data from the MOT). For instance in 1980, 323 area truck licenses and 4 route licenses were transferred and these numbers are fairly typical of the other years too. Murao (p. 110) suggests that the majority of these instances were the result of mergers or bankruptcies which also epitomizes the sale of truck licenses under the US regulatory regime. Unfortunately, the prices at which these licenses were transferred was apparently not reported to the MOT. But the fact that these transfers occurred at all evidences the market value of the licenses. Why bother obtaining a license from its current holder rather than 
obtaining one gratis from the MOT unless the latter avenue was thwarted?

A further hint of the market for trucking licenses in Japan is an item from a trade publication. Okano (1979, p. 76) notes that around 1970 a route trucker based in Shizuoka prefecture and exiting from the industry was unsuccessful in finding a buyer for his license. This was reported in an industry daily under the headline "route trucking licenses already valueless". As Okano remarks, this could only have been newsworthy if in general or prior to this the licenses were not valueless; perhaps that particular route was poorly situated. On the other hand, saleable licenses exist in Japan for shipping routes on coastal waterways and for taxis, and the markets in which these licenses are traded are relatively open. The market for trucking licenses is remarkable by its near absence. Besides the outright sale of licenses, we should also consider the possibilities of indirect leasing of them which may equally evidence that the licenses hold market value. A common practice in the Japanese trucking industry is referred to as "commissioning of vehicles" (in Japanese, yousha, written with the same Chinese character as used in the Japanese word for mercenary soldier: youhei). The difference between the commission payments to hired trucks and drivers and revenues received includes the pro rata rent accruing to the holder of the license. The standard industry practice has been and continues to be to pay commissioned trucks and drivers 90 percent of the revenues their service generates, the licenseholder/permitholder retaining 10 percent. But this is comparable to the percentage of revenues awarded to freight forwarders and thus represents essentially no economic rent. Under the pre-1980 US regulatory regime, the analogous transfer payment from private (unlicensed) backhaulers to licenseholders was as much as 20 to 30 percent of revenues (Robyn (1987, pp. 1920). It seems from this that the rent value of trucking licenses/permits is considerably less under the Japanese regulations than under the old US ones, possibly even zero or nearly so. This does not imply that commercial truckers would suffer no economic losses if the regulations were abolished. Under the status quo, private truckers in Japan are legally enjoined from offering commercial services. If this restraint were to be lifted, the supply of trucking 
services would be enlarged and in the transition to a new (zero profit) equilibrium commercial truckers would suffer losses and some would exit.

Because private truckers mainly deliver merchandise to customers, most of their transport is unidirectional, and the empty return trips simply add to their costs of delivery. They could lower their costs by supplying their backhaul services to others but under the Japanese regulations they can only legally transport their own goods, not those of third parties. Nor according to the letter of the law are commercial truckers permitted to hire the backhaul services of private truckers, for in the case of one company commissioning a vehicle (and driver) from another company, both companies are required to hold licenses pertaining to the business at hand. Ways have been found of getting around these onerous restrictions, but they may not be very common.

A sort of ruse has become widely remarked. A private trucker, technically speaking, "leases" its trucks and maintenance services to the drivers who are then free --as individuals-- to enter their own contracts with licensed truck companies without violating the law (Murao, 1982, pp. 220-221). Others have blatantly ignored the regulations altogether, offering services illegally, sans permit as so-called shiro toora (lit. blank trucks, i.e. trucks with blank or nonexistent permit numbers). The MOT and the Japan Truck Association continue to regard blank trucks as a problem (because they pose a threat to public safety, maintain the officials of these entities).

Just how common it is for private truckers to evade restrictions on their supplying commercial services on the side is difficult to say. But judging from statistics on empty backhauls it may not be very common at all. The percentage of kilometers run which are under load is a measure of the extent of empty backhauls. For trucks that are used only to transport goods, not for commuting, errands and so on, a value of this statistic of .5 would indicate all backhauls are empty. In fact, this is very nearly the case for ordinary (not small-sized) private trucks (See table 5a). Ordinary commercial trucks apparently experience empty backhauls approximately two-thirds of the time (percentage of kilometers which are under load $=.68$ (See tables 5a, 5b, and 5c). This points to a 
possible deadweight loss from regulation. We will return to this point in our final assessment of truck transport regulation in Japan. But before attempting a final assessment, we accumulate more facts about the industry, based on estimates of cost functions.

\section{Cost function estimates.}

Estimates of cost functions for Japanese trucking firms reveal several things. First, neither area trucking firms nor route trucking firms exhibit scale economies. Second, trucking firms experienced virtually no cost-reducing innovation during the 1980's. Third, area trucking firms based in Tokyo and Osaka have significantly higher costs of transporting goods than do others, controlling for the effects of input prices. And finally, area trucking firms experienced no significant shift in cost functions coincident with the 1990 changes in regulation.

The cost functions we estimate here are of the following sort:

$$
c=c(y, t, w),
$$

where $c=$ cost per firm, $y=$ output per firm, $t=$ characteristics of output, and $w=a$ vector of factor prices. Output $y$ is defined as metric tons shipped. of course a given increment of output defined in this way encompasses heterogeneous activities. Accordingly, we shall suppose that the costs of "output" depend also on additional characteristics of the transport process: $t_{1}=$ metric tons per truckday, and $t_{2}=k i l o m e t e r s$ under load per truck-day. For given output as defined here, these two desiderata fairly narrowly circumscribe the number of trips per day, the average distance per haul, and the average weight per load, none of which were observed directly.

For local trucks, we observe data averaged over firms in each of nine geographic regions of Japan annually from 1981 through 1993. For route trucks, we observe data averaged over firms in each of five categories of truck fleet size, annually from 1981 through 1990. The source of data for both route 
truckers and area truckers, 1980-1990 is: unyushou jidousha koutsū kyoku soumuka (general affairs section, automotive transport bureau, ministry of transport, government of Japan), jidousha unsou jigyou keiei shihyou (indicators of automotive transport enterprise management), annual. The sample of firms in this source includes trucking firms that in 1964 derived more than half of their income from this business and in each year a random sample of firms in the smallest category (fewer than 20 trucks). And from 1991-1993, the data on area trucks are from: zeñ nihoñ torakku kyoukai (Japan truck association) keiei buñseki houkoku sho (management analysis report). The sample on which this source is based excludes companies that rely extensively on commissioned vehicles; it favors somewhat smaller. firms than the source of data for the earlier years. ${ }^{6}$

The factors of production are labor, fuel and capital. The wage rate is computed as the compensation per employee. The fuel price is proxied by expenditures on fuel per thousand kilometers travelled. Capital expenses represent the expenses allocated to depreciation, maintenance, and repairs plus five percent of the book value of tangible assets. The remaining portion of operating costs, largely representing commission payments for purchased transportation, were allocated on a pro-rata basis to labor, fuel and capital in the same proportions as the other costs. The capital price is computed as capital expenses (i.e. depreciation, maintenance, and repairs plus five percent of the book value of tangible assets) relative to the book value of tangible assets.

The specific form we estimate is the following?:

$$
\ln c=\alpha_{0}+\sum_{\mathrm{T}} \alpha_{\mathrm{T}}+\sum_{\mathrm{F}} \alpha_{\mathrm{F}}+\sum_{\mathrm{i}} \beta_{\mathrm{i}} \ln \mathrm{w}_{\mathrm{i}}+\sum_{\mathrm{j}} \gamma_{\mathrm{j}} \ln \mathrm{t}_{\mathrm{j}}+\lambda \ln \mathrm{y}+\epsilon,
$$

'Unfortunately the break occurs with the change in regulations. After 1990 the MOT ceased reporting cost data on firms in the separate categories of route trucking and area trucking as it did before.

${ }^{7}$ We also attempted to estimate transcendental logarithmic cost functions of the sort reported by Friedlaender and spady (1981) for US trucking firms, and report the results of one of these. See the appendix for compete details. 
where the $\alpha_{T}$ are time effects, and the $\alpha_{F}$ are firm-type effects (Firm types are distinguished by geographic region in the case of area trucks and by truck fleet size in the case of route trucks). The coefficient $\lambda(=\partial \ln c / \partial \ln y)$, known as the cost "flexibility", indicates the degree of scale economies in production (If $\lambda>1$ there exist diseconomies of scale, and if $\lambda<1$ there are economies of scale).

We follow a standard procedure and estimate the cost function jointly with factor share equations, derived by applying shephard's lemma to the cost function ${ }^{8}$ :

$$
w_{i} x_{i} / c=\beta_{i}+\epsilon .
$$

The fact that cost shares sum to one causes the system to be overdetermined. To state the point a little differently, if we estimate the system with one of the cost share equations removed; the remaining one is uniquely determined.

The tables 6 and 7 display estimates of the cost functions of route trucking firms and area trucking firms, respectively. The year dummies in the route trucking cost estimates indicate differences in intercept between 1980 and each other year in the sample. The firm-type dummies in the route trucking cost estimates indicate differences in intercept between firms with fewer than 20 trucks and those with other fleet sizes. The year dummies in the are trucking cost estimates indicate differences in intercept between 1981 and each other year in the sample. The firm-type dummies in the area trucking cost estimates indicate differences in intercept between Sapporo and each other MOT region. The coefficients on the natural logarithms of factor prices equal the respective factor shares.

The costs are sensitive to the characteristics of output. For given amount of tons transported, costs rise with metric tons per truck day and fall with kilometers per truck day. More tons per truck day means greater consolidation

\footnotetext{
${ }^{8}$ Shephard's lemma holds that: $\quad \partial \ln c / \partial \ln x_{i}=w_{i} x_{i} / c$.
} 
of shipments. More kilometers per truck day means transport over a greater distance. Neither type of truck firm exhibits economies of scale: Cost flexibility is near unity in all the equations. ${ }^{9}$

The firm-type effects were insignificant in the route truckers' costs, which is a further indication that scale economies are not present for these firms. Area truckers in Osaka and Tokyo exhibit higher costs than others. Perhaps these higher costs are related in some way to the urban density of these regions.

The year dummies might be informative regarding technical change, and, in the case of area truckers, informative also regarding the effects on costs of regulatory changes adopted in 1990. First, consider technical change. There does not appear a downward trend or drift over time in the cost functions of either group during the period of observation. The individual dummies themselves are for the most part near zero and not statistically significant. Technical change is strikingly absent from these data. But what of the well-documented innovativeness of Yamato and other route truckers offering parcel delivery service in the 1980's? Almost certainly, Yamato is not in the data set (I am unable to confirm this but the remarkable growth in Yamato's output 1985-1990 does not appear to be reflected in the data).

In the case of area trucking firms, year dummies for 1991-1993 would pick up shifts in cost due to the changes beginning in 1991 permitting area truckers for the first time to consolidate the cargoes of differing customers. There is no dramatic shift apparent.

This investigation of trucking cost functions has revealed an industry in which firms do not exhibit scale economies, and in which for the great mass of firms little cost-reducing innovation is apparent over the previous decade. Armed with these findings, we return our attention to the effects of regulation in this industry.

${ }^{9}$ Our estimates can be compared with those of Chiba. In Chiba (1988) he constructed a divisia index of route trucking input prices 1971-1985, and in Chiba (1991) used this to estimate a simple translog cost function with output represented by tons shipped by the industry in each year. Chiba did find economies of scale (cost flexibility equalling about .5), but his estimate relies upon a much smaller sample than ours and he did not control for characteristics of output. 
5. The economic effects of truck transport regulation and deregulation in Japan Since 1951 the ministry of transport has been vested with sweeping authority to restrict entry and set prices in commercial trucking. Perhaps it could have used this authority to cartelize the industry. The weight of evidence holds that it did not do so. A couple of antimonopoly cases are revealing on the ineffectiveness of price and entry regulations in this industry. In the Okayama truck association case (March 31, 1983, kañkoku shin̄ketsu), the 699 area truck companies in okayama prefecture agreed among themselves (in January 1981) to limits on the sizes of truck fleets, and maximum weights of loads, and further agreed that applications by any of them to the MOT to obtain additional license or expand operations would first have to be submitted for approval of the association (Takimoto (1993), pp. 176-183). The Fair Trade Commission learned of these activities and found them to violate Japan's antimonopoly laws, and the association consented to cease the offending behavior. The significant point about this case is that in spite of the existing regulatory restrictions on pricing and entry, the Okayama truck association nevertheless perceived that collusive restrictions on productive capacity would be advantageous. Because of the absence of diseconomies of scale, the entry restriction in and of itself had very little impact on prices and profits. And apparently the MOT price regulations were not enforced, for if they were, restrictions on output would have been redundant.

A second case involves the route trucker section of the Kanagawa prefecture truck association (March 31, 1989, buñshou kañkoku). In this case, in January 1988 the route truckers based in Kanagawa prefecture agreed to a schedule of minimum prices, based on the standard price schedules announced by the Mот. In other words, the collusive prices would be automatically adjusted upward by the same percentage as any MOT adjustment in standard rates. The Fair Trade Commission investigated and learned that the truck associations of Nagano and Hiroshima prefectures had also engaged in similar behavior. All were found to have violated antimonopoly laws and agreed to desist (Takimoto (1993), pp.184189). Here is yet further evidence that price regulation has been ineffective 
in the truck transport industry.

We can now understand that the difficulties Yamato experienced in expanding its system of parcel delivery in the late 1980's represented a singular case in which the licensing of route truckers constrained growth. Up to that time regulation had not conferred monopoly rents on trucking firms nor significantly inhibited competitive pricing. Its one binding effect had been to constrict the ability of private truckers to offer commercial services. But with the growth of parcel delivery service, regulatory constraints began to bind in other places. Propelled by the American examples of Federal Express and United Parcel Service, Yamato, Nittsuu and others developed a product innovation that was highly successful, and profitable. So profitable in fact that beginning about 1983 these began marketing products directly to consumers to increase the demand for their parcel service (Saitou (1993, pp. 100-106). As the parcel delivery service expanded, the distorting effects of regulation grew larger. As Yamato and others sought to establish nationwide logistical networks, route licenses in selected areas became valuable. The firms were prepared to offer door-to-door pickup and delivery service, utilizing wireless communication with drivers, but were constrained to follow set routes with predefined dropsites. And as customers learned of the convenience and cheapness of parcel service the regulatory distortions were becoming visible.

Becker (1983) has cogently argued that deadweight losses from government policies have precisely the same effects as taxes on political pressure in support of the policies. By superior facility at political organization or effective rhetoric a pressure group may overcome the disadvantage which deadweight losses impose upon it, but without such a boost it is unlikely to prevail. Symmetrically, a pressure group in favor of a policy that eliminates a deadweight loss holds an inherent political advantage, which opposing factions must overcome if they are to thwart it. The relaxation of constraints on parcel delivery service relatively soon after its initial growth spurt eliminated deadweight losses which were growing and widely visible, and should therefore be regarded as unsurprising in light of Becker's theory. But the 1989 Motor Vehicle 
Act contained other provisions besides those strictly related to parcel delivery service. To understand why, another theory is helpful.

Peltzman (1979) developed some of the comparative static properties of political equilibrium. If a political decisionmaker is viewed as maximizing the intensity of support from all pressure groups, then rather than favoring one group to the exclusion of others it will spread rents among them, eliciting equal marginal increases in political support per dollar conferred on each. If a change in external circumstances confers additional possibility of government largess, then policies will be enacted that benefit the many rather than the few. In the opposite case, losses will be subdivided rather than concentrated. The relaxation of constraints on parcel delivery service eliminated deadweight losses. Parcel delivery firms experienced profits and as they expanded and pushed down prices, consumers benefitted. But the 1989 law also relaxed a constraint on area truckers, unnecessary to the freeing of parcel delivery service. Area truckers were enabled to take on less-than-truckload cargoes. (But we were unable to detect any shift in cost functions resulting form this, nor has their been any striking increase in metric-tons per truck day nor reduction in kilometers under load per truck-day for area truckers (See table 8a and 8b)). Additionally, by establishing minimum truck fleet sizes (owned and not leased) and other such preconditions for issuance of a permit the 1989 at least held the possibility of hardened entry requirements in area trucking. In particular this assured area truckers that the prohibition on private truckers from engaging in commercial business would be perpetuated, to the benefit of commercial truckers and detriment of consumers who would continue to suffer from inefficient organization of the trucking industry. As Peltzman's argument requires, the regulations were changed in a way to benefit the many.

\section{Conclusion.}

There is little to suggest that the standard price schedules which the MOT continues to publicize and periodically revise are anything more than suggestions, widely disregarded by commercial trucking firms. There are no 
economies or diseconomies of scale and firms have expanded until industry profits are exhausted. The principle effect of entry restrictions has been to inhibit private truckers from offering commercial services on the side. Commercial truckers desire that this inhibition continue only because their prices and profits would temporarily dip if it were to be lifted. The private truckers desire that the restrictions on their undertaking commercial operations be lifted. Commercial truckers are better organized than private truckers. The Japan truck association has a national office in Tokyo and local chapters in each prefecture. The largest chapters such as the one in Osaka have a permanent staff of professional analysts and advocates. Private truckers by definition derive only a portion of their incomes from trucking operations and so represent a more diffused interest than commercial truckers. Consumers represent an even more diffused interest. Complete deregulation of trucking seems unlikely in the near future. 
Appendix. Translog cost function.

The translog specification allows characteristics, output and factor prices to influence costs in a nonhomothetic fashion. The specific form is:

$$
\begin{aligned}
\operatorname{lnc}= & \alpha_{0}+\sum_{\mathrm{T}} \alpha_{\mathrm{T}}+\sum_{\mathrm{F}} \alpha_{\mathrm{F}}+\sum_{\mathrm{i}} \beta_{\mathrm{i}} \ln \mathrm{w}_{\mathrm{i}}+\sum_{\mathrm{j}} \gamma_{\mathrm{j}} \ln \mathrm{t}_{\mathrm{j}} \\
& +1 / 2 \sum_{\mathrm{i}} \sum_{1} A_{\mathrm{i}} \ln \mathrm{w}_{\mathrm{i}} \ln \mathrm{w}_{\mathrm{i}}+\sum_{\mathrm{i}} \sum_{\mathrm{j}} \mathrm{B}_{\mathrm{ij}} \ln \mathrm{w}_{\mathrm{i}} \ln \mathrm{t}_{\mathrm{j}} \\
& +\sum_{\mathrm{i}} \mathrm{c}_{\mathrm{i}} \ln \mathrm{w}_{\mathrm{i}} \ln \mathrm{l}+1 / 2 \sum_{\mathrm{j}} \sum_{\mathrm{m}} \mathrm{D}_{\mathrm{jm}} \ln \mathrm{t}_{\mathrm{j}} \ln \mathrm{t}_{\mathrm{m}} \\
& +\sum_{\mathrm{j}} \mathrm{E}_{\mathrm{j}} \ln \mathrm{t}_{\mathrm{j}} \ln \mathrm{ln}+1 / 2 \mathrm{~F}(\ln \mathrm{y})^{2}+\epsilon
\end{aligned}
$$

By Shephard's lemma the factor share equations become:

$$
w_{i} x_{i} / c=\beta_{i}+\sum_{1} A_{i l} \ln w_{1}+\sum_{j} B_{i j} \ln t_{j}+c_{i} \ln y+\epsilon .
$$

And the cost function is homogeneous of degree one in all input prices, which entails the following restrictions:

$$
\begin{aligned}
& \sum_{\mathrm{i}} \beta_{\mathrm{i}}=1 \\
& \sum_{\mathrm{i}} \mathrm{A}_{\mathrm{il}}=0, \quad \mathrm{~A}_{\mathrm{il}}=\mathrm{A}_{\mathrm{li}} \\
& \sum_{\mathrm{i}} \mathrm{B}_{\mathrm{ij}}=0 \\
& \sum_{\mathrm{i}} \mathrm{C}_{\mathrm{i}}=0 .
\end{aligned}
$$

I attempted to estimate this cost function jointly with factor share equations for both route trucking firms 1980-1990 (55 observations) and area trucking firms 1981-1993 (117 observations) but did not obtain sensible results. Removal of all second-order terms yields the specification adopted in the text of this paper. For area truckers, a specification in which only the second-order terms based on the fuel price were set equal to zero also produced comparable results to those reported in the text. The following table fully reports this estimate. 


\section{References}

Becker, Gary (1983). "A Theory of Competition Among Pressure Groups for Political Influence", Quarterly Journal of Economics, volume 98, pp.371-400.

Chiba, Yoshio (1988a). Divisia shūkei ni yoru torakku yūsou sañgyou no seisan̄sei no keisoku ni tsuite (on the measurement of productivity in the truck transport industry by Divisia aggregates) Mita shougaku keñkyū, vol. 3 , no. 4 (October), pp. 62-77.

Chiba, Yoshio (1988b) i roseñ torakku jigyou no shijou kouzou ni tsuite no teiryouteki kousatsu (a quantitative consideration of route trucking firms' market structure) Mobility (Fall), pp. 52-58.

Frew, James R. (1981). "The Existence of Monopoly Profits in the Motor Carrier Industry", Journal of Law and Economics, vol. 24, pp. 289-315.

Friedlaender, Ann F. and Richard H. Spady (1981). Freight Transport Regulation: Equity, Efficiency, and competition in the Rail and Trucking Industries, The MIT Press.

Goto, Akira and Talehiko Sugiyama (1983. "Economic Regulation in the Japanese Trucking Industry", International fournal of Transport Economics, vol. 10, no. 1-2 (April-August), pp. 327-339.

Ligon, Gray (1993). "The Japanese Expansion of U.S. Air Express Service: 19851990", Ch. 17 in M. Czinkota and M. Kotabe, eds.' The Japanese Distribution System, Probus Publishing Co.: Chicago, pp. 251-258.

Moore, Thomas Gale (1978). "The Beneficiaries of Trucking Regulation", Journal fo Law and Economics, vol. 21, pp. 327-343.

Murao, Tadashi (1982). kamotsu yusou no jidoushaka--señgo katei no keizai buñseki (motorization of freight transport--economic analysis of the postwar process) hakutou shobou (shinagawa daigaku keizai boueki kenkyū saishou dai-nigo).

Okano, Yukihide (1979). riku uñ san̄gyou kai--sañgyoukai shirīzu 140 (land transport industry-industry series no. 140) kyoikusha shiñsho.

Peltzman, Sam (1976). "Toward a More General Theory of Regulation", Journal of Law and Economics, vol. 19, pp. 211-240.

Peltzman, Sam (1989). "The Economic Theory of Regulation After a Decade of Deregulation", Brookings Papers on Economic Activity.

Robyn, Dorothy (1987). Braking the Special Interests, Trucking Deregulation and the politics of policy

Reform, The University of Chicago Press, 1987.

Saitou, Minoru (1991). takuhaibiñ -- geñdai yusou no inobētā (parcel delivery service-innovator in today's transport) seizañdou shoteñ.

Sugiyama (1989). torakku yusou (truck transport), Ch. 10, in: M. Okuno, M. Shinohara and $Y$. Kanemoto, eds., koutsū seisaku no keizaígaku (economics of transport policy), nihoñ keizai shiñbuñsha, pp. 225-244.

Takahashi, Hideo (1990), "Japan Moves to Deregulate Trucking Industry", JEI Report, no. 17A, (April 27).

Takeuchi, T. and I. Terada (1995). douro kamotsu yusou (road freight transport, Ch. 6 in: Yoshitsugu Kanemoto and Hirotaka Yamauchi, eds., kouza-kouteki kisei to sangyou, 4: koutsū (study group--public regulation and industry, 4: transport), pp. 233-266, NTT shuppañ kabushiki kaisha.

Takimoto, Mineo (1993). kamotsu jidousha uñsou jigyou keiei to dokuseñ kin̄shi hou --dokuseñ kinshi hou to uwate ni tsukiau tame ni (antimonopoly laws and the management of truck transport enterprises --towards better familiarity with the antimonopoly laws), dai-ichi houki shuppañ kabushiki kaisha.

uñyushou uñyu seisaku kyoku jouhou kan̄ri bu (information management section, transport policy bureau, ministry of transport). uñyu toukei yourañ (land transport statistics survey), 1995 edition.

unyushou jidousha koutsū kyoku soumuka (general affairs section, automotive transport bureau, ministry of transport, government of Japan), jidousha unsou jigyou keiei shihyou (indicators of automotive transport enterprise management), annual.

zeñ nihoñ torakku kyoukai (Japan truck association) keiei buñseki houkoku sho (management analysis report), 1993 edition (publication date $=1995$ ). 
Appendix table. Regression estimate of translog cost function; area truckers 1981-1993.

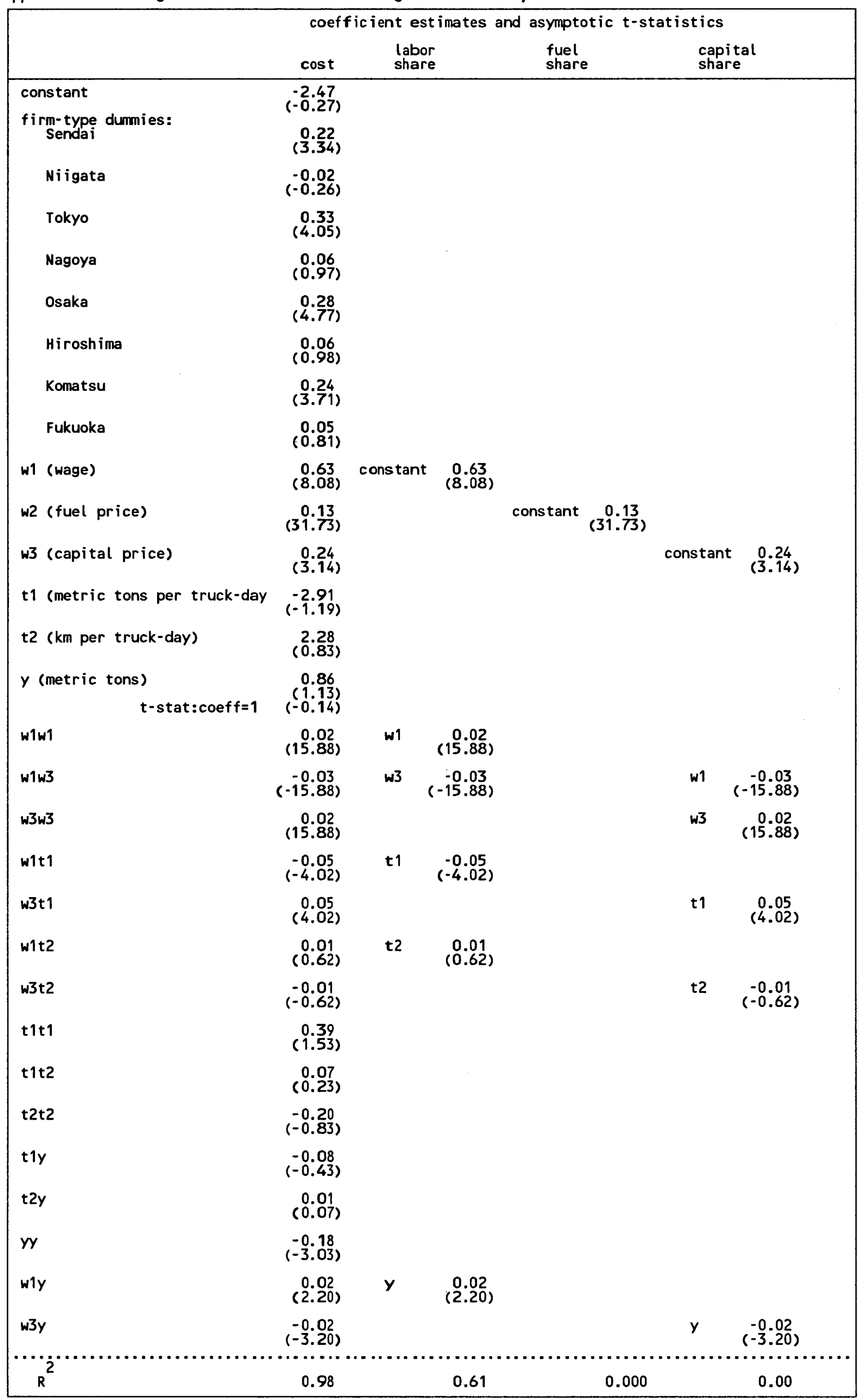


Table 1. Numbers of trucking companies.

$$
\begin{array}{ll}
\text { route } & \text { area } \\
\text { trucking } & \text { trucking } \\
\text { firms } & \text { firms } \\
\text { (less-than- } & \text { (full } \\
\text {-truckload) } & \text { truckload) }
\end{array}
$$

$\begin{array}{lrr}\text { year } & & \\ 1955 & 528 & 8,323 \\ 1960 & 533 & 13,017 \\ 1965 & 489 & 19,368 \\ 1970 & 425 & 22,560 \\ 1975 & 379 & 28,253 \\ 1980 & 356 & 31,334 \\ 1981 & 355 & 31,792 \\ 1982 & 352 & 32,162 \\ 1983 & 347 & 32,513 \\ 1984 & 343 & 32,661 \\ 1985 & 337 & 33,201 \\ 1986 & 336 & 33,841 \\ 1987 & 332 & 33,471 \\ 1988 & 329 & 35,168 \\ 1989 & 325 & 35,888 \\ 1990 & 297 & 36,485 \\ 1991 & 292 & 37,387 \\ 1992 & 290 & 38,569 \\ 1993 & 287 & 39,627\end{array}$

Source. uñyushou uñyu seisaku kyoku jouhou kan̄ri bu (information management section, transport policy bureau, ministry of transport). uñyu toukei yourañ (land transport statistics survey), 1995 edition, table 3-1, p.73.

Table 2. Operating income of regulated trucking firms. units= millions of yen.

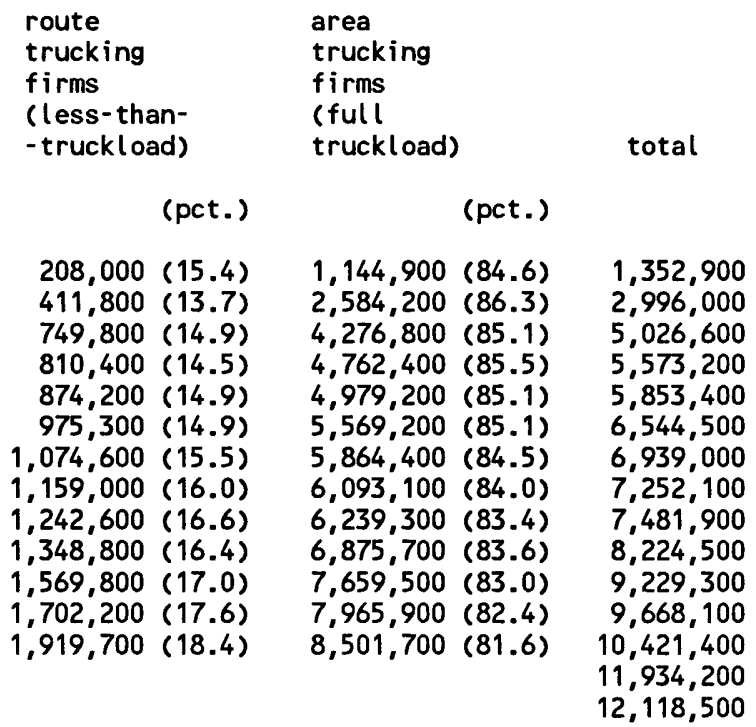

Source. uñyushou uñyu seisaku kyoku jouhou kan̄ri bu (information management section, transport policy bureau, ministry of transport). uñyu toukei yourañ (land transport statistics survey), 1995 edition, table 1-1, p. 5. 
Table 3. Transport by trucks.

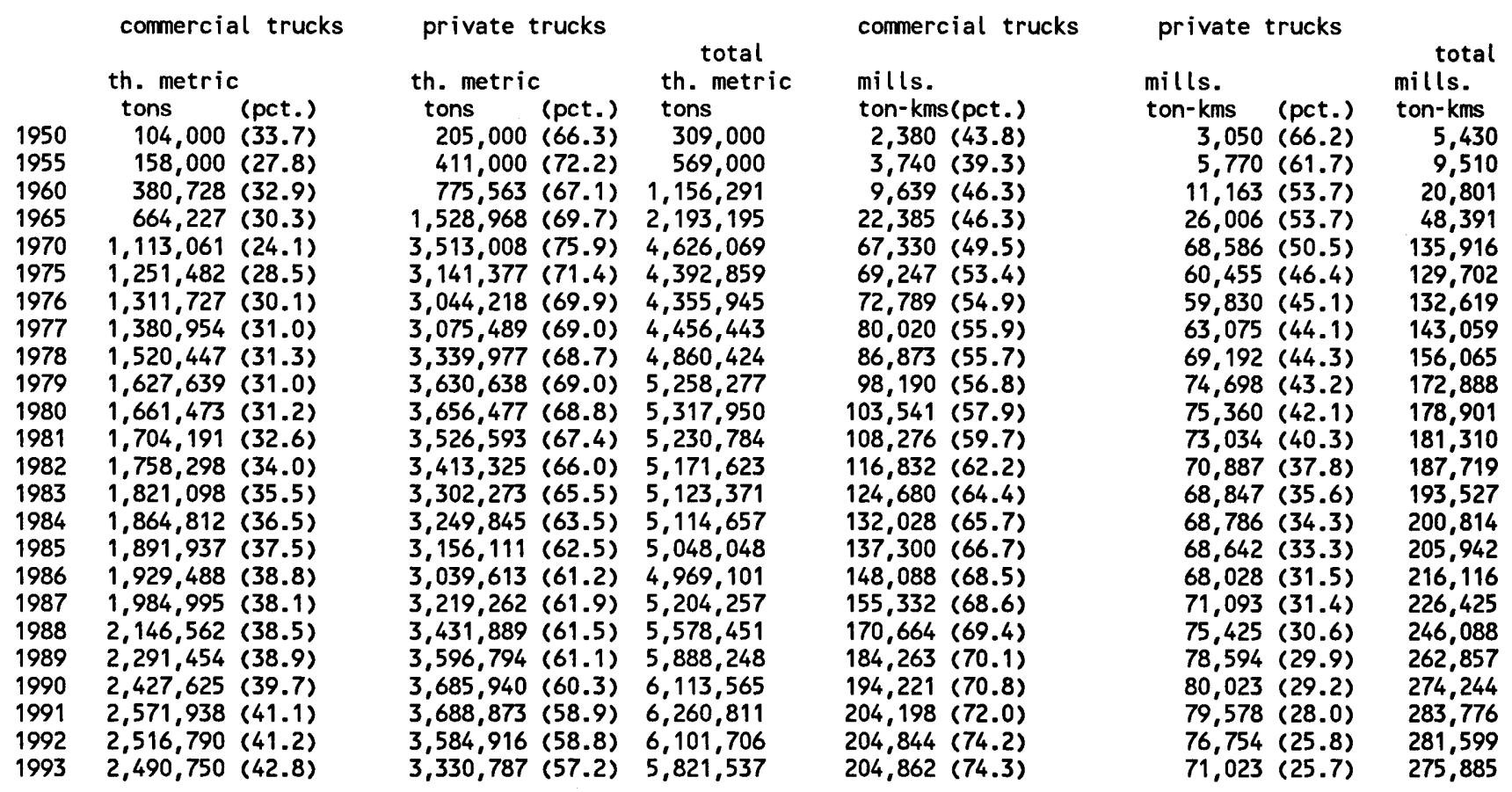

Source. uñyushou uñyu seisaku kyoku jouhou kan̄ri bu (information management section, transport policy bureau, ministry of transport). uñyu toukei yourañ (land transport statistics survey), 1995 edition, table 2-5, pp.15-20. 
Table 4. Volume of parcels transported. units $=10,000$ parcels

\begin{tabular}{|c|c|}
\hline $\begin{array}{l}\text { postal } \\
\text { parcels }\end{array}$ & JR \\
\hline
\end{tabular}

$\begin{array}{lrrr}1955 & 6,684 & 4,520 & \\ 1960 & 9,958 & 6,625 & \\ 1965 & 13,777 & 7,890 & \\ 1970 & 19,572 & 7,540 & \\ 1975 & 15,649 & 7,935 & \\ 1976 & 17,880 & 7,199 & \\ 1977 & 18,778 & 6,294 & \\ 1978 & 19,122 & 5,471 & \\ 1979 & 19,925 & 4,936 & \\ 1980 & 18,392 & 4,152 & \\ 1981 & 15,603 & 3,492 & 10,682 \\ 1982 & 13,854 & 2,843 & 17,395 \\ 1983 & 13,266 & 2,090 & 27,782 \\ 1984 & 14,064 & 1,572 & 38,490 \\ 1985 & 15,098 & 1,230 & 49,303 \\ 1986 & 16,305 & 688 & 61,248 \\ 1987 & 19,561 & & 76,244 \\ 1988 & 23,500 & & 91,125 \\ 1989 & 29,760 & & 102,854 \\ 1990 & 35,143 & & 110,050 \\ 1991 & 40,812 & & 112,484 \\ 1992 & 42,600 & & 118,337 \\ 1993 & 40,054 & & 123,710\end{array}$

Source. uñyushou uñyu seisaku kyoku jouhou kañri bu (information and research department, transport policy bureau, ministry of transport) uñyu keizai toukei yourañ (national transportation statistics handbook), 1994 edition, p.36. 
Table 5a. Percentage of kilometers run which are under load (jissha ritsu), ordinary trucks (not small trucks)

\begin{tabular}{lll} 
year & commercial & private \\
\hline 1960 & 66.0 & 44.8 \\
1965 & 64.5 & 49.8 \\
1970 & 64.1 & 51.2 \\
1975 & 62.9 & 52.0 \\
1980 & 65.5 & 54.4 \\
1985 & 69.1 & 56.4 \\
1990 & 68.9 & 51.8 \\
1991 & 68.2 & 51.4 \\
1992 & 68.1 & 50.7 \\
1993 & 67.0 & 50.1 \\
\hline
\end{tabular}

Source. uñyushou uñyu seisaku kyoku jouhou kan̄ri bu (information and research department, transport policy bureau, ministry of transport) uñyu keizai toukei yourañ (national transportation statistics handbook), 1994 edition, table 2-6, p.19.

Table 5b. Percentage of kilometers run which are under load (jissha ritsu), area trucks.

\begin{tabular}{cccccc} 
year & \multicolumn{1}{c}{ size of truck fleet } & & \\
$11-20$ & $21-50$ & $51-100$ & $101-$ \\
\hline 1985 & 60.2 & 65.7 & 62.8 & 65.5 & 72.1 \\
1986 & 60.6 & 65.9 & 62.3 & 65.6 & 72.1 \\
1987 & 62.9 & 64.0 & 63.4 & 65.7 & 72.4 \\
1988 & 61.1 & 62.3 & 65.3 & 58.0 & 72.2 \\
1989 & 57.7 & 63.4 & 65.1 & 65.9 & 71.2 \\
1990 & 57.5 & 62.8 & 65.5 & 64.1 & 72.7 \\
& & & & & \\
1991 & 62.4 & 68.4 & 70.9 & 71.9 & 73.5 \\
1992 & 63.1 & 67.4 & 69.4 & 72.4 & 71.5 \\
1993 & 62.2 & 67.0 & 69.4 & 70.4 & 72.2
\end{tabular}

Sources:

1985-1990: unyushou jidousha koutsū kyoku soumuka (general affairs section, automotive transport bureau, ministry of transport, government of Japan), jidousha unsou jigyou keiei shihyou (indicators of automotive transport enterprise management), annual.

1991-1993:: zeñ nihoñ torakku kyoukai (Japan truck association) keiei buñseki houkoku sho (management analysis report), 1993 edition (publication date =1995).

Table 5c. Percentage of kilometers run which are under load (jissha ritsu), route trucks.

\begin{tabular}{cccccc} 
year & size of truck fleet & & \\
& $1-20$ & $21-50$ & $51-100$ & $101-300$ & $300-$ \\
\hline 1985 & 90.7 & 90.4 & 90.4 & 93.6 & 97.0 \\
1986 & 91.9 & 89.8 & 94.1 & 92.8 & 97.3 \\
1987 & 91.3 & 90.0 & 93.9 & 93.4 & 97.2 \\
1988 & 89.1 & 91.3 & 93.9 & 94.1 & 97.2 \\
1989 & 88.4 & 92.4 & 92.4 & 94.5 & 97.1 \\
1990 & 87.9 & 92.1 & 94.1 & 94.5 & 96.8 \\
\hline
\end{tabular}


Table 6. Regression estimates of cost functions; route truckers 1980-1990.

\begin{tabular}{|c|c|c|c|}
\hline \multirow[b]{2}{*}{ constant } & \multicolumn{3}{|c|}{$\begin{array}{l}\text { coefficient estimates and } \\
\text { asymptotic } t-s t a t i s t i c s\end{array}$} \\
\hline & $\begin{array}{l}-2.21 \\
(-2.63)\end{array}$ & $\begin{array}{c}1.13 \\
(1.29)\end{array}$ & $\begin{array}{c}1.71 \\
(1.93)\end{array}$ \\
\hline \multicolumn{4}{|l|}{ year dummies: } \\
\hline 1981 & $\begin{array}{c}-0.01 \\
(-0.40)\end{array}$ & $\begin{array}{l}-0.08 \\
(-0.18)\end{array}$ & \\
\hline 1982 & $\begin{array}{l}-0.02 \\
(-0.73)\end{array}$ & $\begin{array}{l}-0.01 \\
(-0.30)\end{array}$ & \\
\hline 1983 & $\begin{array}{l}-0.00 \\
(-0.14)\end{array}$ & $\begin{array}{l}-0.03 \\
(-0.71)\end{array}$ & \\
\hline 1984 & $\begin{array}{l}0.05 \\
(1.89)\end{array}$ & $\begin{array}{l}-0.02 \\
(-0.37)\end{array}$ & \\
\hline 1985 & $\begin{array}{c}0.06 \\
(2.12)\end{array}$ & $\begin{array}{l}-0.04 \\
(-0.97)\end{array}$ & \\
\hline 1986 & $\begin{array}{c}0.07 \\
(2.58)\end{array}$ & $\begin{array}{l}-0.08 \\
(-2.01)\end{array}$ & \\
\hline 1987 & $\begin{array}{c}0.11 \\
(3.50)\end{array}$ & $\begin{array}{l}-0.06 \\
(-1.23)\end{array}$ & \\
\hline 1988 & $\begin{array}{c}0.17 \\
(5.35)\end{array}$ & $\begin{array}{l}-0.02 \\
(-0.53)\end{array}$ & \\
\hline 1989 & $\begin{array}{c}0.23 \\
(7.23)\end{array}$ & $\begin{array}{l}0.03 \\
(0.55)\end{array}$ & \\
\hline 1990 & $\begin{array}{l}0.24 \\
(7.04)\end{array}$ & $\begin{array}{l}0.04 \\
(0.85)\end{array}$ & \\
\hline \multicolumn{4}{|l|}{ firm-type dummies: } \\
\hline 20 to 50 trucks & $\begin{array}{l}-0.07 \\
(-0.46)\end{array}$ & & \\
\hline 50 to 100 trucks & $\begin{array}{c}0.14 \\
(0.58)\end{array}$ & & \\
\hline 100 to 300 trucks & $\begin{array}{l}0.07 \\
(0.20)\end{array}$ & & \\
\hline 300 or more trucks & $\begin{array}{l}0.33 \\
(0.62)\end{array}$ & & \\
\hline w1 (wage) & $\begin{array}{c}0.60 \\
(113.22)\end{array}$ & $\begin{array}{c}0.60 \\
(114.30)\end{array}$ & $\begin{array}{c}0.60 \\
(117.80)\end{array}$ \\
\hline W2 (fuel price) & $\begin{array}{r}0.08 \\
(23.48\end{array}$ & $\begin{array}{c}0.08 \\
(23.68)\end{array}$ & $\begin{array}{c}0.08 \\
(24.50)\end{array}$ \\
\hline w3 (capital price) & $\begin{array}{c}0.32 \\
(45.31)\end{array}$ & $\begin{array}{c}0.32 \\
(45.66)\end{array}$ & $\begin{array}{c}0.32 \\
(46.90)\end{array}$ \\
\hline t1 (metric tons per truck-day) & $\begin{array}{l}-0.73 \\
(-4.57)\end{array}$ & $\begin{array}{l}-1.11 \\
(-5.49)\end{array}$ & $\begin{array}{l}-0.98 \\
(-8.17)\end{array}$ \\
\hline t2 (km per truck-day) & $\begin{array}{l}0.62 \\
(4.42)\end{array}$ & $\begin{array}{l}0.22 \\
(1.37)\end{array}$ & $\begin{array}{l}0.07 \\
(0.41)\end{array}$ \\
\hline $\begin{array}{l}y \text { (metric tons) } \\
\qquad t-\text { stat: } \operatorname{coe} f f=1\end{array}$ & $\begin{array}{c}0.87 \\
(7.51) \\
(-1.10)\end{array}$ & $\begin{array}{r}1.01 \\
(39.21) \\
(0.55)\end{array}$ & $\begin{array}{r}1.03 \\
(38.50) \\
(1.27)\end{array}$ \\
\hline
\end{tabular}


Table 7. Regression estimates of cost functions; area truckers 1981-1993.

\begin{tabular}{|c|c|c|c|c|}
\hline \multirow[b]{2}{*}{ constant } & \multicolumn{2}{|c|}{$\begin{array}{l}\text { coefficient estimates and } \\
1980-1990\end{array}$} & \multicolumn{2}{|c|}{$\begin{array}{r}\text { asymptotic } t-s t a t i s t i c s \\
\text { translog }\end{array}$} \\
\hline & $\begin{array}{c}0.27 \\
(0.48)\end{array}$ & $\begin{array}{c}0.23 \\
(0.39)\end{array}$ & $\begin{array}{c}0.51 \\
(0.99)\end{array}$ & $\begin{array}{l}-2.47 \\
(-0.27)\end{array}$ \\
\hline \multicolumn{5}{|l|}{ year dummies: } \\
\hline 1982 & $\begin{array}{c}0.01 \\
(0.26)\end{array}$ & $\begin{array}{c}0.00 \\
(0.08)\end{array}$ & & \\
\hline 1983 & $\begin{array}{l}-0.00 \\
(-0.13)\end{array}$ & $\begin{array}{c}-0.03 \\
(-0.71)\end{array}$ & & \\
\hline 1984 & $\begin{array}{l}-0.00 \\
(-0.10)\end{array}$ & $\begin{array}{l}-0.04 \\
(-0.97)\end{array}$ & & \\
\hline 1985 & $\begin{array}{c}0.02 \\
(0.74)\end{array}$ & $\begin{array}{c}-0.02 \\
(-0.45)\end{array}$ & & \\
\hline 1986 & $\begin{array}{l}0.02 \\
(0.73)\end{array}$ & $\begin{array}{c}-0.03 \\
(-0.89)\end{array}$ & & \\
\hline 1987 & $\begin{array}{c}0.06 \\
(1.82)\end{array}$ & $\begin{array}{c}-0.01 \\
(-0.27)\end{array}$ & & \\
\hline 1988 & $\begin{array}{c}0.11 \\
(3.09)\end{array}$ & $\begin{array}{c}0.04 \\
(0.97)\end{array}$ & & \\
\hline 1989 & $\begin{array}{c}0.12 \\
(3.22)\end{array}$ & $\begin{array}{c}0.04 \\
(1.02)\end{array}$ & & \\
\hline 1990 & $\begin{array}{c}0.10 \\
(2.65)\end{array}$ & $\begin{array}{c}0.03 \\
(0.67)\end{array}$ & & \\
\hline 1991 & & $\begin{array}{c}-0.09 \\
(-1.44)\end{array}$ & & \\
\hline 1992 & & $\begin{array}{c}-0.03 \\
(-0.43)\end{array}$ & & \\
\hline 1993 & & $\begin{array}{c}-0.09 \\
(-1.48)\end{array}$ & & \\
\hline \multicolumn{5}{|l|}{ firm-type dummies: } \\
\hline Senda $i$ & $\begin{array}{c}0.30 \\
(4.24)\end{array}$ & $\begin{array}{l}0.20 \\
(2.46)\end{array}$ & $\begin{array}{c}0.25 \\
(3.72)\end{array}$ & $\left(2 . \frac{22}{34}\right)$ \\
\hline Ni igata & $\begin{array}{c}0.00 \\
(0.06)\end{array}$ & $\begin{array}{c}-0.04 \\
(-0.54)\end{array}$ & $\begin{array}{c}0.02 \\
(0.31)\end{array}$ & $\begin{array}{c}-0.02 \\
(-0.26)\end{array}$ \\
\hline Tokyo & $\begin{array}{c}0.55 \\
(8.78)\end{array}$ & $\begin{array}{c}0.38 \\
(6.26)\end{array}$ & $\begin{array}{c}0.41 \\
(7.46)\end{array}$ & $\begin{array}{c}0.33 \\
(4.05)\end{array}$ \\
\hline Nagoya & $\begin{array}{l}0.07 \\
(1.15)\end{array}$ & $\begin{array}{l}-0.02 \\
(-0.27)\end{array}$ & $\begin{array}{c}0.01 \\
(0.25)\end{array}$ & $\begin{array}{c}0.06 \\
(0.97)\end{array}$ \\
\hline Osaka & $\begin{array}{c}0.39 \\
(7.54)\end{array}$ & $\begin{array}{c}0.27 \\
(4.09)\end{array}$ & $\begin{array}{c}0.32 \\
(6.61)\end{array}$ & $\begin{array}{c}0.28 \\
(4.77)\end{array}$ \\
\hline Hiroshima & $\begin{array}{c}0.09 \\
(1.58)\end{array}$ & $\begin{array}{c}0.01 \\
(0.14)\end{array}$ & $\begin{array}{c}0.07 \\
(1.36)\end{array}$ & $\begin{array}{c}0.06 \\
(0.98)\end{array}$ \\
\hline Komatsu & $\begin{array}{c}0.01 \\
(0.09)\end{array}$ & $\begin{array}{l}-0.05 \\
(-0.78)\end{array}$ & $\begin{array}{c}-0.01 \\
(-0.18)\end{array}$ & $\begin{array}{l}0.23 \\
(3.71)\end{array}$ \\
\hline Fukuoka & $\begin{array}{c}0.15 \\
(2.51)\end{array}$ & $\begin{array}{c}0.03 \\
(0.44)\end{array}$ & $\begin{array}{c}0.11 \\
(2.02)\end{array}$ & $\begin{array}{c}0.05 \\
(0.81)\end{array}$ \\
\hline w1 (wage) & $\begin{array}{c}0.53 \\
(102.60)\end{array}$ & $\begin{array}{c}0.53 \\
(120.66)\end{array}$ & $\begin{array}{c}0.53 \\
(123.80)\end{array}$ & $\begin{array}{c}0.73 \\
(8.08)\end{array}$ \\
\hline w2 (fuel price) & $\begin{array}{c}0.13 \\
(29.18)\end{array}$ & $\begin{array}{c}0.13 \\
(31.67)\end{array}$ & $\begin{array}{c}0.13 \\
(32.47)\end{array}$ & $\left(\begin{array}{c}0.13 \\
(31.73)\end{array}\right.$ \\
\hline w3 (capital price) & $\begin{array}{c}0.34 \\
(63.57)\end{array}$ & $\begin{array}{c}0.34 \\
(71.08)\end{array}$ & $\begin{array}{c}0.34 \\
(72.44)\end{array}$ & $\begin{array}{c}0.24 \\
(3.14)\end{array}$ \\
\hline t1 (metric tons per truck-day) & $\left(\begin{array}{l}-0.87 \\
(-10.61)\end{array}\right.$ & $\begin{array}{c}-0.98 \\
(-14.29)\end{array}$ & $\begin{array}{c}-0.97 \\
(-14.53)\end{array}$ & $\begin{array}{l}-2.91 \\
(-1.19)\end{array}$ \\
\hline t2 (km per truck-day) & $\begin{array}{c}0.41 \\
(4.18)\end{array}$ & $\begin{array}{l}0.50 \\
(4.47)\end{array}$ & $\begin{array}{l}0.43 \\
(4.64)\end{array}$ & $\begin{array}{l}2.28 \\
(0.83)\end{array}$ \\
\hline $\begin{array}{l}y \text { (metric tons) } \\
\qquad t-\text { stat: coef } f=1\end{array}$ & $\begin{array}{r}1.02 \\
(21.96) \\
(0.34)\end{array}$ & $\begin{array}{r}1.04 \\
(20.91) \\
(0.73)\end{array}$ & $\begin{array}{c}1.09 \\
(38.87) \\
(3.27)\end{array}$ & $\begin{array}{c}0.86 \\
(1.13) \\
(-0.14)\end{array}$ \\
\hline
\end{tabular}

* Translog specification includes additional terms, not shown here. See appendix for complete estimates. 
Table 8a. metric tons per truck-day (t1), area trucks.

\begin{tabular}{cccccc} 
year & $\begin{array}{c}\text { size of truck fleet } \\
1-10\end{array}$ & $11-20$ & $21-50$ & $51-100$ & $101-$ \\
\hline 1985 & 13 & 17 & 19 & 15 & 14 \\
1986 & 17 & 18 & 16 & 16 & 13 \\
1987 & 12 & 17 & 14 & 15 & 14 \\
1988 & 18 & 19 & 14 & 16 & 15 \\
1989 & 13 & 16 & 17 & 17 & 14 \\
1990 & 20 & 25 & 14 & 17 & 13 \\
1991 & 24 & 19 & 13 & 12 & 11 \\
1992 & 22 & 17 & 13 & 11 & 12 \\
1993 & 17 & 15 & 12 & 11 & 11 \\
\hline
\end{tabular}

Sources:

1985-1990: unyushou jidousha koutsū kyoku soumuka (general affairs section, automotive transport bureau, ministry of transport, government of Japan), jidousha unsou jigyou keiei shihyou (indicators of automotive transport enterprise management), annual.

1991-1993: : zeñ nihoñ torakku kyoukai (Japan truck association) keiei buñseki houkoku sho (management analysis report), 1993 edition (publication date $=1995$ ).

Table 8 b. kilometers per truck-day (t2), area trucks.

\begin{tabular}{cccccc} 
year & $\begin{array}{c}\text { size of truck fleet } \\
1-10\end{array}$ & $11-20$ & $21-50$ & $51-100$ & $101-$ \\
\hline 1985 & 109 & 131 & 121 & 131 & 150 \\
1986 & 111 & 136 & 110 & 134 & 151 \\
1987 & 111 & 133 & 120 & 138 & 161 \\
1988 & 131 & 128 & 128 & 121 & 162 \\
1989 & 102 & 133 & 128 & 145 & 159 \\
1990 & 123 & 132 & 123 & 135 & 170 \\
1991 & 165 & 132 & 167 & 172 & 168 \\
1992 & 161 & 138 & 158 & 164 & 172 \\
1993 & 155 & 126 & 157 & 161 & 167 \\
\hline
\end{tabular}

Sources:

1985-1990: unyushou jidousha koutsū kyoku soumuka (general affairs section, automotive transport bureau, ministry of transport, government of Japan), jidousha unsou jigyou keiei shihyou (indicators of automotive transport enterprise management), annual.

1991-1993: : zeñ nihon̄ torakku kyoukai (Japan truck association) keiei buñseki houkoku sho (management analysis report), 1993 edition (publication date $=1995$ ). 